Article

\title{
Superparamagnetic Iron Oxide Nanoparticles Modified with Silica Layers as Potential Agents for Lung Cancer Treatment
}

\author{
Katarzyna Reczyńska ${ }^{1,2}$, Marta Marszałek ${ }^{3 \oplus}{ }^{\circledR}$ Arkadiusz Zarzycki $^{3}{ }^{\circledR}$, Witold Reczyński ${ }^{1}$, \\ Kamil Kornaus ${ }^{1}$, Elżbieta Pamuła ${ }^{1, * \mathbb{D}}$ and Wojciech Chrzanowski ${ }^{2, *}$ \\ 1 Faculty of Materials Science and Ceramics, AGH University of Science and Technology, Al. Mickiewicza 30, \\ 30-059 Kraków, Poland; kmr@agh.edu.pl (K.R.); wreczyn@agh.edu.pl (W.R.); kornaus@agh.edu.pl (K.K.) \\ 2 Sydney Nano Institute, Faculty of Medicine and Health, Sydney School of Pharmacy, \\ The University of Sydney, Pharmacy and Bank Building, Camperdown, NSW 2006, Australia \\ 3 Institute of Nuclear Physics, Polish Academy of Sciences, ul. Radzikowskiego 152, 31-342 Kraków, Poland; \\ marta.marszalek@ifj.edu.pl (M.M.); arkadiusz.zarzycki@ifj.edu.pl (A.Z.) \\ * Correspondence: epamula@agh.edu.pl (E.P.); wojciech.chrzanowski@sydney.edu.au (W.C.); \\ Tel.: +48-12-617-44-48 (E.P.); +61-2-9351-5306 (W.C.)
}

Received: 15 April 2020; Accepted: 25 May 2020; Published: 31 May 2020

\begin{abstract}
Superparamagnetic iron oxide nanoparticles (SPIONs) are promising drug delivery carriers and hyperthermia agents for the treatment of cancer. However, to ensure their safety in vivo, SPIONs must be modified in order to prevent unwanted iron release. Thus, SPIONs were coated with silica layers of different morphologies: non-porous $\left(@ \mathrm{SiO}_{2}\right)$, mesoporous $\left(@ \mathrm{mSiO}_{2}\right)$ or with a combination of non-porous and mesoporous layers $\left(@ \mathrm{SiO}_{2} @ \mathrm{mSiO}_{2}\right)$ deposited via a sol-gel method. The presence of $\mathrm{SiO}_{2}$ drastically changed the surface properties of the nanoparticles. The zeta potential changed from $19.6 \pm 0.8 \mathrm{mV}$ for SPIONs to $-26.1 \pm 0.1 \mathrm{mV}$ for SPION@ $\mathrm{mSiO}_{2}$. The Brunauer-Emmett-Teller (BET) surface area increased from $7.54 \pm 0.02 \mathrm{~m}^{2} / \mathrm{g}$ for SPIONs to $101.3 \pm 2.8 \mathrm{~m}^{2} / \mathrm{g}$ for SPION@ $\mathrm{mSiO}_{2}$. All types of coatings significantly decreased iron release (at least 10 fold as compared to unmodified SPIONs). SPIONs and SPION@ $\mathrm{mSiO}_{2}$ were tested in vitro in contact with human lung epithelial cells (A549 and BEAS-2B). Both nanoparticle types were cytocompatible, although some delay in proliferation was observed for BEAS-2B cells as compared to A549 cells, which was correlated with increased cell velocity and nanoparticles uptake.
\end{abstract}

Keywords: lung cancer; nanoparticles; nanoformualtions; controlled drug release; drug delivery; superparamagnetic iron oxide nanoparticles (SPIONs); silica coating; iron release; nano-bio-characterization; Atomic Force Microscopy

\section{Introduction}

Superparamagnetic iron oxide nanoparticles (SPIONs) consist of magnetite $\left(\mathrm{Fe}_{3} \mathrm{O}_{4}\right)$ or maghemite $\left(\gamma-\mathrm{Fe}_{2} \mathrm{O}_{3}\right)$. The methods of SPIONs synthesis are well established, enabling the fabrication of uniform nanoparticles of the desired size and shape [1,2]. SPIONs have already been explored for a vast variety of biomedical purposes, including magnetic resonance imaging (MRI) [3,4], tissue engineering [5,6] and cell separation [7]. Due to their unique magnetic properties, they gained a lot of interest in the field of controlled drug delivery [8,9], photodynamic therapy [10,11] and hyperthermia [12,13], thus SPIONs are regarded as one of the most promising candidates for the development of novel methods for cancer treatment. Numerous studies utilized SPIONs for magnetically mediated hyperthermia-a concept based on the fact that the viability of malignant cells is lower at temperatures above $41^{\circ} \mathrm{C}$ in comparison to non-malignant cells [14,15]. SPIONs can be accumulated directly at the tumor site 
and heated up using an external alternating magnetic field [13]. The unique magnetic properties of SPIONs, e.g., high magnetization values and superparamagnetism, make them particularly useful as hyperthermia agents [16]. The efficacy of such a treatment may be increased by the simultaneous delivery of anticancer drugs or biologically active molecules. Lachowicz et al. [17] synthesized SPIONs decorated with curcumin conjugated with sodium alginate. The nanoparticles with an average diameter of $50 \mathrm{~nm}$ were proved to be suitable for hyperthermia treatment. Mansouri et al. [18] encapsulated paclitaxel in nanoparticles composed of palmitoyl chitosan and SPIONs. The study showed that the release profile of paclitaxel was changed by the application of a magnetic field. The developed hybrid nanoparticles enhanced the apoptosis of MCF-7 cells due to hyperthermia effects coupled with an increased concentration in paclitaxel in cells.

Conventionally, SPIONs are destined for subcutaneous or intravenous administration [19]. However, in the case of lung cancer, pulmonary delivery of the drug is more effective, allows for the reduction of systemic toxicity of the treatment and increases patients' compliance [20]. Sadhukha et al. [21] showed that it is possible to effectively deliver epidermal growth factor (EGFR) targeted SPIONs directly to the lungs via inhalation, resulting in a uniform distribution of the nanoparticles in the lungs. The administration of EGFR-targeted SPIONs was followed by magnetic hyperthermia, which not only significantly inhibited tumor growth, but also did not cause any damage to healthy tissues or other side effects. Another advantage of using SPIONs as pulmonary drug delivery carriers is the possibility for the guided accumulation of the nanoparticles only in the affected parts of the lungs using an external magnetic field. Price et al. [22] fabricated SPION-loaded lactose microparticles containing doxorubicin and confirmed the feasibility of the targeted accumulation of SPIONs in selected lung lobes in mice. They found that the amount of SPIONs in a magnetized left lung lobe was 10 times higher than in the right lobe.

Despite those promising results, some issues connected with the use of SPIONs for the treatment of lung cancer still need to be solved. One of the major concerns is related to the dissolution of SPIONs and the possible release of iron that can actually promote cancer growth [23]. If SPIONs are supposed to be delivered directly to the tumor site and be used for the induction of hyperthermia and the killing of the cancer cells, they should not supply those cells with iron and stimulate their growth at the same time. Therefore, it is indispensable to modify their surface to prevent iron release. Unfortunately, the majority of the studies focused on SPIONs neglect that aspect. Surface modifications of SPIONs are mostly aimed at the improvement of their colloidal stability (coating with poly(ethylene glycol)_PEG [24] or poly(vinyl alcohol)_PVA [25]), biocompatibility (coating with natural polymers such as alginate [26] or chitosan [18]) or the attachment of various biologically active ligands (functionalization with PEG or gold [27]). However, in terms of the inhibition of iron release, the modification of SPIONs with stable silica coatings seems to be the most appropriate. Such coatings are commonly used to protect materials from corrosion [28] and offer numerous advantages, including the ease of deposition and microstructure modification [29]. Furthermore, SPIONs were already extensively tested in vitro in contact with different cell types (e.g., MCF-7 breast cancer cell line [30], primary human umbilical cord vein endothelial cells (HUVECs) [31] or in different types of malignant cell lines containing folic acid receptors (FARs) [32]). However, the information on the influence of SPIONs on lung epithelial cells of malignant or non-malignant origin is yet scarce.

Hence, the aim of this study was to modify SPIONs in order to develop a versatile platform for lung cancer diagnosis and therapy. SPIONs were coated with silica layers with different microstructures that were supposed to: (1) decrease iron release from the nanoparticles, (2) generate a high surface area available for further loading with anticancer drugs or other biologically active moieties, and (3) maintain their magnetic properties suitable for biomedical applications. Modified SPIONs were evaluated using various physicochemical methods. In the end, their cytocompatibility with lung epithelial cells was also determined. 


\section{Materials and Methods}

\subsection{Materials}

Superparamagnetic iron (II,III) oxide nanoparticles (SPIONs), tetraethyl orthosilicate (TEOS) and hexadecyltrimethylammonium bromide (CTAB) were purchased from Sigma-Aldrich (St. Louis, MO, USA). Ethanol (99.9\%), ammonia (28\%), potassium ferrocyanide and hydrochloric acid (35\%) were of analytical grade and were purchased from Avantor Performance Materials, Poland S.A. Ultra-high quality water (UHQ-water) was produced in a UHQ-PS purification system (Elga, High Wycombe, UK). All reagents were used without additional purification.

The liquid mixture used for the fabrication of the silica coating consisted of ethanol $(99.8 \%)$, UHQ-water and ammonia (28\%) (further referred to as Et/UQH/Am) in the following volumetric ratio: ethanol/UHQ-water/ammonia 32:8:1.

\subsection{Modification of SPIONs}

SPIONs were coated with different types of silica layers: non-porous $\left(@ \mathrm{SiO}_{2}\right)$, mesoporous $\left(@ \mathrm{mSiO}_{2}\right)$ or with a combination of non-porous and mesoporous layers $\left(@ \mathrm{SiO}_{2} @ \mathrm{mSiO}_{2}\right)($ Figure 1$)$. Silica layers were deposited on the SPIONs with the use of TEOS as a silica precursor and CTAB as a pore former (for $@ \mathrm{mSiO}_{2}$ coatings only) using a sol-gel technique [28,33].

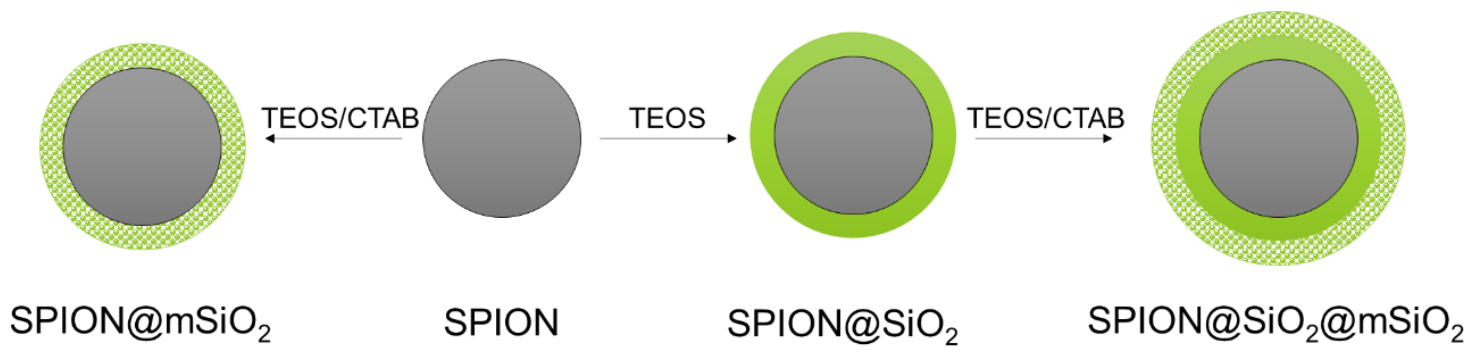

Figure 1. Schematic representation of the modification of superparamagnetic iron oxide nanoparticles (SPIONs).

\subsubsection{Non-Porous Silica Coating $\left(@ \mathrm{SiO}_{2}\right)$}

One gram of SPIONs was suspended in $200 \mathrm{~mL}$ of Et/UHQ/Am and homogenously dispersed using an ultrasound probe (40\% amplitude, $30 \mathrm{~min}$, Vibra-Cell, Sonic \& Materials, Inc., Newtown, CT, USA). One milliliter of TEOS was added dropwise into the suspension and ultrasound homogenization was continued for $5 \mathrm{~min}$. The suspension was then aliquoted into polypropylene falcon tubes and vigorously mixed using a vortex mixer (500 rpm, VX-200, Labnet International, Big Flats, NY, USA) for $12 \mathrm{~h}$. The obtained silica coated SPIONs (SPION@SiO $\left.{ }_{2}\right)$ were collected by solid-liquid separation using an external neodymium magnet, washed three times with $25 \mathrm{~mL}$ ethanol and three times with $25 \mathrm{~mL}$ UHQ-water, followed by air drying overnight at $60^{\circ} \mathrm{C}$.

\subsubsection{Mesoporous Silica Coating $\left(@ \mathrm{mSiO}_{2}\right)$}

One gram of SPIONs or SPION@SiO 2 was suspended in 175 mL Et/UHQ/Am and homogenized using an ultrasound probe (40\% amplitude, $15 \mathrm{~min})$. One gram of CTAB, previously dissolved in $25 \mathrm{~mL} \mathrm{Et} / \mathrm{UHQ} / \mathrm{Am}$, was added into the suspension. Ultrasound homogenization was continued for another $15 \mathrm{~min}$ followed by the dropwise addition of $1 \mathrm{~mL}$ of TEOS. After $5 \mathrm{~min}$ of ultrasound homogenization, the suspension was aliquoted into polypropylene falcon tubes and was vigorously mixed using a vortex mixer $(500 \mathrm{rpm})$ for $12 \mathrm{~h}$. Mesoporous silica coated SPIONs $\left(\mathrm{SPION} @ \mathrm{mSiO}_{2}\right)$ or SPIONs coated with combined non-porous and mesoporous silica coatings $\left(\mathrm{SPION} @ \mathrm{SiO}_{2} @ \mathrm{mSiO}_{2}\right)$ were collected, washed three times with $25 \mathrm{~mL}$ ethanol and three times with $25 \mathrm{~mL}$ UHQ-water and air 
dried overnight at $60{ }^{\circ} \mathrm{C}$. Additional thermal treatment of SPIONs with @ $\mathrm{mSiO}_{2}$ coatings (dwelling at $250{ }^{\circ} \mathrm{C}, 2 \mathrm{~h}$ ) was performed to remove trace remnants of CTAB.

\subsection{Physiochemical Characterization}

\subsubsection{Fourier Transform Infrared Spectroscopy (FTIR)}

FTIR of the nanoparticles was performed using a Bruker Tensor 27 spectrophotometer (Bruker). SPIONs were embedded in $\mathrm{KBr}$ pellets and the transmission spectra were recorded at $4000-425 \mathrm{~cm}^{-1}$ with a $4 \mathrm{~cm}^{-1}$ resolution. For each sample, 64 single scans were collected. The obtained spectra were analyzed using OPUS software.

\subsubsection{Magnetic Properties}

The magnetic properties of the nanoparticles were investigated using a SQUID magnetometer (Quantum Design MPMS XL, San Diego, CA, USA). Accurately weighted nanoparticles (12 mg) were placed inside a gelatin capsule and immobilized by GE Varnish glue (Cryospares ${ }^{\mathrm{TM}}$, Abingdon, UK). The magnetization of the nanoparticles was measured at $300 \mathrm{~K}$ as a function of a magnetic field in the range of $\pm 50 \mathrm{kOe}$.

\subsubsection{Transmission Electron Microscopy (TEM)}

The nanoparticles were suspended in UHQ-water and sonicated for $5 \mathrm{~min}$ ( $30 \%$ amplitude). The suspension droplets were put on formvar-coated copper grids (200 mesh, Creative Bioarray, Shirley, NY, USA). After blotting and drying, the specimens were observed with an FEI Tecnai 12 Biotwin microscope (FEI, Hillsboro, OR, USA) using a Gatan Orius SC1000 CCD camera (Gatan, Inc., Pleasanton, CA, USA).

\subsubsection{Atomic Force Microscopy (AFM)}

The morphology and surface stiffness of the SPIONs and SPION@ $\mathrm{mSiO}_{2}$ were evaluated using AFM. The nanoparticles were suspended in UHQ-water and dispersed using an ultrasound probe ( $20 \%$ amplitude, $10 \mathrm{~min}$ ). A drop of suspension was then placed on a clean mica disc (Agar Scientific, Stansted, UK) coated with poly-L-lysine ( $0.1 \%$, Sigma-Aldrich, St. Louis, MO, USA) for $5 \mathrm{~min}$. Excess nanoparticles were washed from the discs using UHQ-water and the remaining nanoparticles were dried in nitrogen flow at room temperature. The topography and phase images of the nanoparticles were recorded using a NanoIR ${ }^{\mathrm{TM}}$ (Anasys Instruments, Santa Barbara, CA, USA) in tapping mode using a silicon nitride probe with a spring constant of 40 N/m (EXT125, AppNano, Mountain View, CA, USA) at a scan rate of $0.5 \mathrm{~Hz}$.

\subsubsection{Surface Zeta Potential}

The surface zeta potential of the nanoparticles was measured using a LiteSizer 500 (AntonPaar, Austria). The nanoparticles were suspended in UHQ-water $(30-50 \mu \mathrm{g} / \mathrm{mL})$ and homogenously dispersed using an ultrasound probe (20\% amplitude, $10 \mathrm{~min})$. The suspension was placed in Omega cuvettes (AntonPaar, Graz, Austria) and three measurements (50 runs for each) were recorded for each sample. The results were analyzed using dedicated Kalliope software (version 1.2.0, AntonPaar, Graz, Austria).

\subsubsection{Surface Area}

The surface area of the nanoparticles was evaluated using the Brunauer-Emmett-Teller (BET) method. Accurately weighted nanoparticles were degassed at room temperature for $24 \mathrm{~h}$ to obtain $2 \mu \mathrm{mHg}$ pressure. The surface area was determined via the multipoint nitrogen adsorption method (ASAP 2000, Micrometric, Norcross, GA, USA). 


\subsubsection{Iron Release}

Fifty milligrams of the nanoparticles were placed in sealed dialysis bags (ZelluTrans/Roth, MWCO: 10-12 kDa, Carl Roth GmbH + Co. KG, Karlsruhe, Germany) immersed in $25 \mathrm{~mL}$ of UHQ-water in falcon tubes. The nanoparticles were incubated for $24 \mathrm{~h}$ at $37^{\circ} \mathrm{C}$ with constant shaking (the tubes were mounted in a horizontal shaker (50 rpm VX-200, Labnet International, Big Flats, NY, USA). The experiment was run in triplicate (three samples for each type of the nanoparticles). The concentration of iron released from the nanoparticles to the surrounding UHQ-water was determined using atomic absorption spectroscopy, electrothermal technique (ET AAS, Perkin Elmer 4100 ZL with Zeeman background correction, Waltham, MA, USA). The measurement was performed using a hollow-cathode lamp (HCL, $\lambda: 248.3 \mathrm{~nm}$, aperture: $0.2 \mathrm{~nm}$ ), the temperature of sample decomposition was set to $1400{ }^{\circ} \mathrm{C}$ and sample atomization to $2400^{\circ} \mathrm{C}$. Each sample was measured in duplicate.

\subsection{In Vitro Cytotoxicity}

SPIONs and SPION@ $\mathrm{mSiO}_{2}$ were selected for the evaluation of in vitro cytotoxicity in contact with human lung epithelial cells. Malignant human lung epithelial cells of lung carcinoma origin (A459, ATCC ${ }^{\circledR}$ CCL-185TM, ATCC, Manassas, VA, USA) and non-malignant human lung epithelial cells of normal lung/bronchus origin (BEAS-2B, ATCC ${ }^{\circledR}$ CRL-9609TM, ATCC, Manassas, VA, USA) were used. Both cell types were cultured in Dulbecco's modified Eagle's medium (DMEM, PAN-Biotech $\mathrm{GmbH}$, Aidenbach, Germany) supplemented with 10\% fetal bovine serum (FBS, South America origin, PAN-Biotech $\mathrm{GmbH}$, Aidenbach, Germany) and 1\% penicillin/streptomycin (PAN-Biotech GmbH, Aidenbach, Germany). In addition, the culture medium for the BEAS-2B cells was supplemented with $1 \%$ glutamine (Gibco ${ }^{\circledR}$ GlutaMAX ${ }^{\mathrm{TM}}$, Life Technologies, Carlsbad, CA, USA). The cells were cultured in a humidified atmosphere at $37^{\circ} \mathrm{C}$ with $5 \% \mathrm{CO}_{2}$.

Unless stated otherwise, the cells were seeded in 96-well plates at 2000 cells/well in $200 \mu \mathrm{L}$ of complete cell culture medium and cultured for $24 \mathrm{~h}$ before the treatment, i.e., the addition of the nanoparticles. All experiments were performed simultaneously on A549 and BEAS-2B cells. The nanoparticles were sterilized using UV light $(\sim 260 \mathrm{~nm}, 30 \mathrm{~min})$ and added to the cells in the cell culture medium at a final concentration of $10 \mu \mathrm{g} / \mathrm{mL}$. The incubation was followed for up to 4 days (depending on assay type). All experiments were run in triplicate.

\subsubsection{Cellular Uptake and Intracellular Release of Iron}

Nanoparticle uptake by A549 and BEAS-2B cells was evaluated qualitatively using Prussian blue and eosin staining, and quantitatively by atomic absorption spectroscopy, electrothermal technique (AAS-ET).

\section{Prussian Blue and Eosin Staining}

A549 and BEAS-2B cells were seeded and treated with SPIONs or SPION@ $\mathrm{mSiO}_{2}$, according to the standard procedure. After $24 \mathrm{~h}$ of incubation with the nanoparticles, the cells were washed two times with $200 \mu \mathrm{L}$ of PBS to remove any non-absorbed nanoparticles, fixed for $20 \mathrm{~min}$ with $3.8 \%$ paraformaldehyde and washed again with $200 \mu \mathrm{L}$ of PBS. The nanoparticles were stained using freshly prepared Prussian blue reagent (the aqueous solution of $5 \%$ potassium ferrocyanide in $10 \%$ hydrochloric acid) for $20 \mathrm{~min}$ [34]. The cells were washed three times with $200 \mu \mathrm{L}$ of PBS. The cytoplasm was counterstained with $1 \%$ eosin (Sigma-Aldrich, St. Louis, MO, USA) for $5 \mathrm{~min}$ and the cells were once again rinsed with $200 \mu \mathrm{L}$ of PBS. The bright field images of the cells were taken using an optical microscope (Axiovert 40 CFL, Zeiss, Oberkochen, Germany).

\section{AAS-ET Analysis}

A549 and BEAS-2B cells were seeded in T25 flat bottom tissue culture flasks at 150,000 cells/flask and allowed to attach to the bottom of the flask. SPIONs or SPION@ $\mathrm{mSiO}_{2}$ were added to the cells $24 \mathrm{~h}$ 
after seeding at $20 \mu \mathrm{g} / \mathrm{mL}$ (the same ratio between the amount of the nanoparticles and the number of cells seeded). Twenty-four hours after the treatment, the cells were washed three times with $3 \mathrm{~mL}$ PBS, collected using $0.25 \%$ trypsin in $1 \mathrm{mM}$ EDTA solution (PAN Biotech $\mathrm{GmbH}$, Aidenbach, Germany) and counted using a Bürker chamber. The concentration of iron in cell suspensions was determined using AAS-ET. The differences in cell number were taken into consideration and thus total the iron content determined via AAS-ET was divided by the average number of cells for each sample. The experiment was performed in triplicate.

\subsubsection{Proliferation and Cytotoxicity}

\section{Real-Time Impedance Measurements}

Cell proliferation was evaluated using a real-time impedance measurement method (xCelligence RTCA SP, ACEA Biosciences, Inc., San Diego, CA, USA). The cells were seeded at 2000 cells/well in 96-well plates with microelectronic cell sensor arrays integrated into the bottom of plates (E-Plate 96, ACEA Biosciences, Inc., San Diego, CA, USA). SPIONs and SPION@ $\mathrm{mSiO}_{2}(10 \mu \mathrm{g} / \mathrm{mL})$ were added to the cell culture medium $28 \mathrm{~h}$ after cell seeding. The incubation of the cells with the nanoparticles was continued for 3 days. Through the whole experiment, the plate was kept inside xCelligence RTCA SP apparatus placed in the incubator $\left(5 \% \mathrm{CO}_{2}, 37^{\circ} \mathrm{C}\right.$, humidified atmosphere) and the impedance was measured every $15 \mathrm{~min}$. The registered impedance values were recalculated and presented as a normalized cell index using the provided xCelligence RTCA SP software (version 1.2.1).

\section{Live/Dead Staining}

Live/dead staining was performed after 3 days of incubation of the cells with SPIONs or SPION@ $\mathrm{mSiO}_{2}$. The culture medium was replaced with FluoroBrite ${ }^{\mathrm{TM}}$ DMEM (Gibco, Life Technologies, Carlsbad, CA, USA) containing 0.1\% calcein AM (Sigma-Aldrich, St. Louis, MO, USA) and $0.1 \%$ propidium iodide (Sigma-Aldrich, St. Louis, MO, USA). The cells were incubated for $20 \mathrm{~min}$. Fluorescent microscopy images were taken using a fluorescence microscope (Axiovert 40 CFL with HXP 120 C Metal Halide Illuminator, Zeiss, Oberkochen, Germany).

Lactate Dehydrogenase (LDH) Assay

The cytotoxicity of SPIONs and SPION@mSiO ${ }_{2}$ was evaluated using an LDH Assay Kit-WST (Dojindo, Kumamoto, Japan). Three days after treatment, $50 \mu \mathrm{L}$ of cell culture supernatant was transferred to an optically clear 96-well plate and mixed with $100 \mu \mathrm{L}$ of the working solution (prepared according to the manufacturer's instructions briefly before the experiment). The plate was incubated in the dark for $30 \mathrm{~min}$ at room temperature. Then $50 \mu \mathrm{L}$ of the stop solution was added into each well. The absorbance at $490 \mathrm{~nm}$ was measured using a microplate reader (VICTOR Multilabel Plate Reader, PerkinElmer, Waltham, MA, USA).

\subsubsection{Cell Migration}

The cells were seeded and treated with the nanoparticles according to the standard procedure. During the whole experiment, the plates were kept inside an IncuCyte ZOOM System (Essen BioScience, Newark Close, UK) and phase contrast images were recorded every $2 \mathrm{~h}$ (four images for each well). The images were then analyzed and compiled into image sets showing the proliferation and migration of the cells in selected areas of the well plate $(1280 \mu \mathrm{m} \times 1726 \mu \mathrm{m})$ using the provided IncuCyte software (version 2016A).

The prepared image sets were analyzed using ImageJ software [35]. The paths travelled by the cells were determined using the Manual Cell Tracking plug-in. The middle of the nuclei of the analyzed cell was marked and its XY coordinates were defined. The cell was followed through all subsequent frames. The difference in $X Y$ values between the frames allowed for the calculation of the distance travelled by the cell within two subsequent images (in $\mu \mathrm{m}$ ). The total distance travelled by the cell was 
determined as a sum of all partitive distances. The velocity of the cell (in $\mu \mathrm{m} / \mathrm{h}$ ) was calculated as the distance between two subsequent frames divided by the time span between those images ( $2 \mathrm{~h}$ interval). For each sample (control, SPIONs or SPION@ $\mathrm{mSiO}_{2}$ treated A549 or BEAS-2B cells) at least 20 cells originating from four different image sets were analyzed. Additionally, all of the cells visible in the images were counted using the Cell Counter plug-in (at least five image sets for each sample group).

\subsection{Statistics}

The statistical analyses of the obtained data were done using a one-way analysis of variance (one-way ANOVA) followed by Tukey's post hoc test. The assumptions of normal distribution and equal variance were verified using the Shapiro-Wilk and Levene median tests, respectively ( $p$-value $<0.05$ ). The analyses were performed using SigmaPlot 12.3 software (Systat Software, Inc., San Jose, CA, USA). The results are presented as mean \pm standard deviation (SD), unless stated otherwise.

\section{Results}

\subsection{Nanoparticle Characterization}

Silica coatings were successfully deposited on the SPIONs as evidenced by FTIR (Figure 2a). The bands originating from the Fe-O bond $\left(565 \mathrm{~cm}^{-1}\right)$ were present in all spectra. The spectra of modified SPIONs exhibited the bands characteristic for $\mathrm{SiO}_{2}$ (Si-O-Si: 800 and $1080 \mathrm{~cm}^{-1}$; Si-OH: $965 \mathrm{~cm}^{-1}$ ). The intensity ratios between the major bands representing $\mathrm{Fe}-\mathrm{O}$ and $\mathrm{Si}-\mathrm{O}-\mathrm{Si}$ bonds increased from 1:0.58 for SPION@SiO 2 to 1:0.88 and 1:1.88 for SPION@mSiO ${ }_{2}$ and $\mathrm{SPION} @ \mathrm{SiO}_{2} @ \mathrm{mSiO}_{2}$, respectively. This indicated the increasing amount of silica deposited on the SPIONs and the effective formation of multiple silica coatings on the SPIONs.
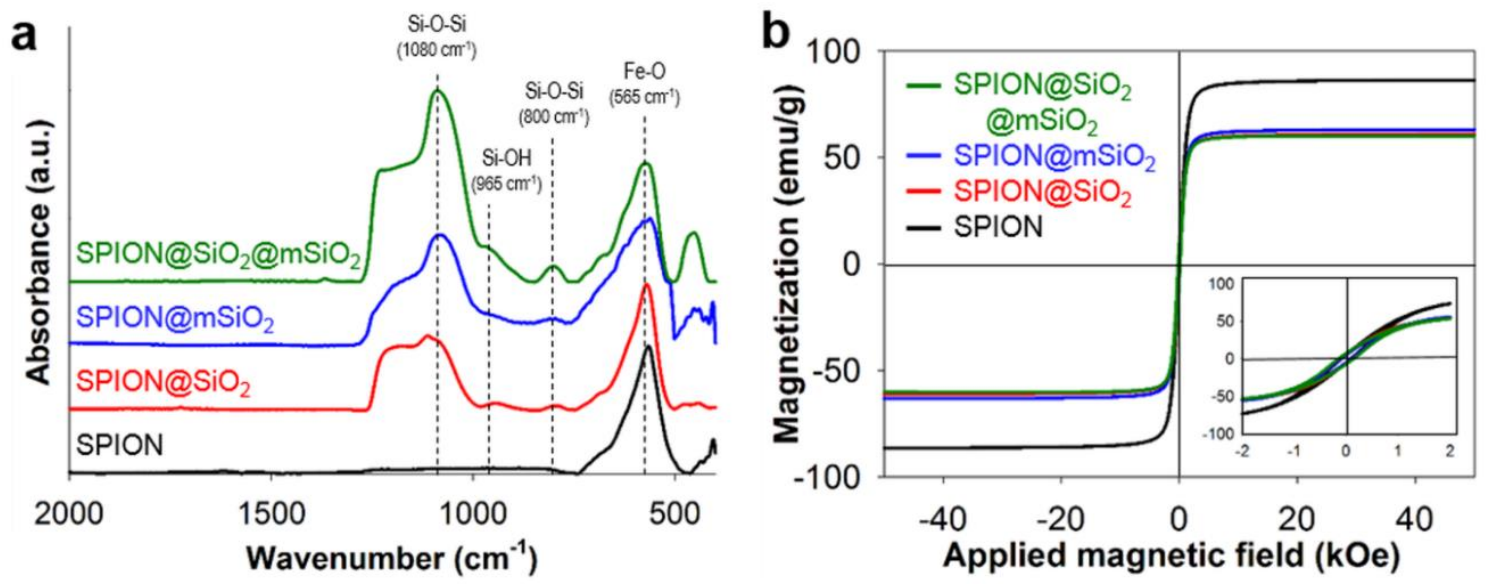

Figure 2. Fourier transform infrared spectroscopy (FTIR) spectra of the nanoparticles (a) and magnetization curves of the nanoparticles at $300 \mathrm{~K}$ (b).

The characterization of the magnetic properties of the modified nanoparticles (Figure $2 \mathrm{~b}$ and Table 1) showed that the highest magnetization saturation $\left(\mathrm{M}_{\mathrm{S}}\right)$ value was measured for the unmodified SPIONs $(86.3 \mathrm{emu} / \mathrm{g})$. The $\mathrm{M}_{\mathrm{S}}$ decreased with the increase in $\mathrm{SiO}_{2}$ content in the nanoparticles (63.1 emu/g for SPION@SiO ${ }_{2}, 61.0 \mathrm{emu} / \mathrm{g}$ for SPION@mSiO 2 and $60.1 \mathrm{emu} / \mathrm{g}$ for SPION@SiO${ }_{2} @ \mathrm{mSiO}_{2}$ ). The differences in the $\mathrm{M}_{\mathrm{S}}$ of the nanoparticles allowed for the determination of the $\mathrm{SiO}_{2}$ content. As expected, the highest $\mathrm{SiO}_{2}$ content was measured for $\mathrm{SPION} @ \mathrm{SiO}_{2} @ \mathrm{mSiO}_{2}(30.4 \%)$, however the amount of $\mathrm{SiO}_{2}$ in both SPION@SiO ${ }_{2}$ and SPION@ $\mathrm{mSiO}_{2}$ was above 25\% (26.8\% and 29.3\%, respectively). The increase in $\mathrm{SiO}_{2}$ content resulted in the increase in the ratio between remanence and magnetization saturation $\left(\mathrm{M}_{\mathrm{R}} / \mathrm{M}_{\mathrm{S}}\right)$ and coercivity $\left(\mathrm{H}_{\mathrm{C}}\right)$. 
Table 1. Magnetic properties of the nanoparticles $\left(\mathrm{M}_{S}-\right.$ magnetization saturation, $\mathrm{M}_{\mathrm{R}}$-remanence, $\mathrm{H}_{\mathrm{C}}$-coercivity).

\begin{tabular}{ccccc}
\hline Sample & $\mathbf{M}_{\mathbf{s}}(\mathbf{e m u} / \mathbf{g})$ & Silica Content at 300K (wt \%) & $\mathbf{M}_{\mathbf{R}} / \mathbf{M}_{\mathbf{S}}$ & $\mathbf{H}_{\mathbf{C}}(\mathbf{O e})$ \\
\hline SPIONs & 86.3 & - & 0.063 & 92 \\
SPION@SiO & 63.1 & 26.8 & 0.084 & 104 \\
SPION@mSiO & 61.0 & 29.3 & 0.109 & 123 \\
SPION@SiO ${ }_{2} @ \mathrm{mSiO}_{2}$ & 60.1 & 30.4 & 0.120 & 143 \\
\hline
\end{tabular}

TEM images of the nanoparticles (Figure 3a) showed that unmodified SPIONs were irregular in shape, with the diameters ranging from 50 to $200 \mathrm{~nm}$. Silica layers were visible on the surface of all the modified SPIONs, however, the most uniform coating was obtained for SPION@mSiO ${ }_{2}$. AFM topography and phase images were also acquired (Figure 3b). According to the literature, drastic changes in phase angles could be correlated with sudden changes in surface stiffness and with the change in surface Young's modulus [36]. In our study, no noticeable changes in AFM phase images were observed for SPION@ $\mathrm{mSiO}_{2}$. This indicated that the deposited coatings were homogenous and uniform in terms of mechanical properties.

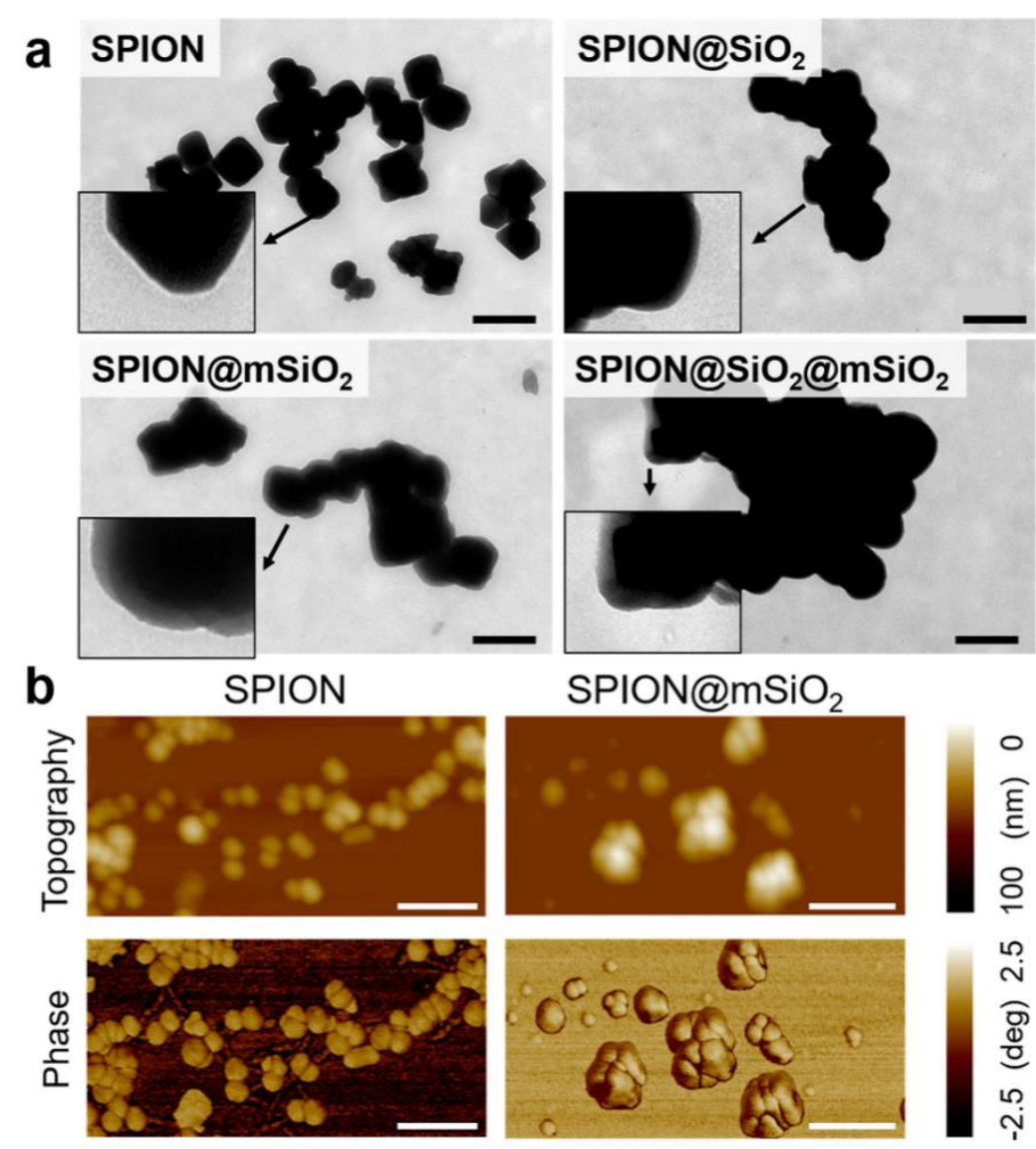

Figure 3. Transmission electron microscopy (TEM) images of the nanoparticles (scale bar $=300 \mathrm{~nm}$, inserts show SPIONs at higher magnification) (a) and atomic force microscopy (AFM) topographical and phase images of SPIONs and SPION@ $\mathrm{mSiO}_{2}($ scale bar = $200 \mathrm{~nm})(\mathbf{b})$.

The modification of SPIONs with silica layers drastically changed the surface properties of the nanoparticles. The surface zeta potential (Figure 4a) was $+19.6 \pm 0.8 \mathrm{mV}$ for unmodified SPIONs and it decreased to $-12.2 \pm 0.3 \mathrm{mV}$ for SPION@ $@ \mathrm{SiO}_{2}$ and $-26.1 \pm 0.1 \mathrm{mV}$ for SPION@ $\mathrm{mSiO}_{2}$. The BET surface area of the nanoparticles (Figure $4 \mathrm{~b}$ ) increased from $7.54 \pm 0.02 \mathrm{~m}^{2} / \mathrm{g}$ for SPIONs to even $101.3 \pm 2.8 \mathrm{~m}^{2} / \mathrm{g}$ for SPION@ $\mathrm{mSiO}_{2}$. The coating of SPIONs with a silica layer decreased iron dissolution and its release 
in UHQ-water at least 10-fold (Figure 4c). A statistically significant difference in the concentration of iron released was observed between unmodified SPIONs and all silica coated ones.
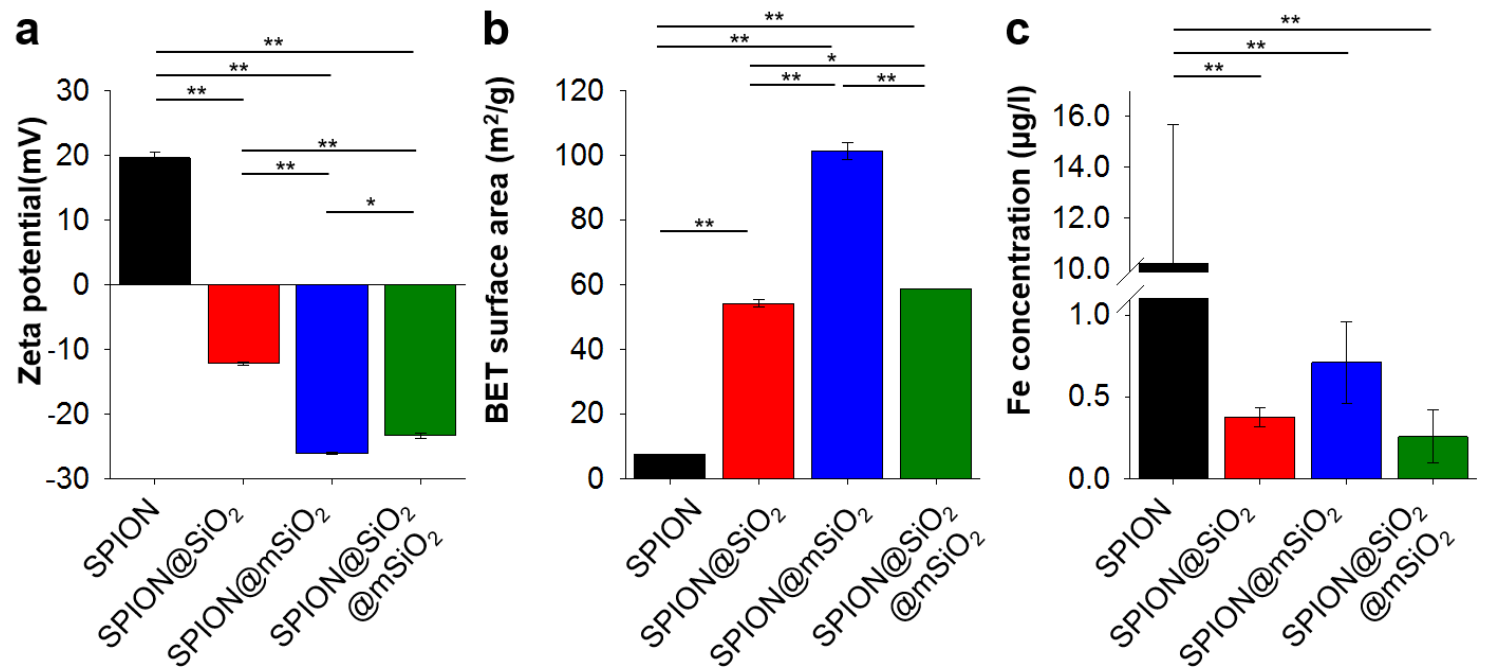

Figure 4. Zeta potential (a), Brunauer-Emmett-Teller (BET) surface area (b) and concentration of iron released from $1 \mathrm{mg}$ of the nanoparticles (c). Statistically significant differences at ${ }^{*} p<0.05$ and ** $p<0.001$.

\subsection{In Vitro Cytotoxicity}

SPIONs and SPION@ $\mathrm{mSiO}_{2}$ were tested in contact with human lung epithelial cells of carcinoma (A549) and normal (BEAS-2B) origin. Both types of the nanoparticles were effectively incorporated by A549 and BEAS-2B cells. The agglomerates of incorporated nanoparticles were clearly visible in optical microscopy images (Figure 5a). As visualized by Prussian blue and eosin staining, the majority of the nanoparticles were stored in the areas in close proximity to cell nuclei. Regardless of the presence of nanoparticles, the cells exhibited typical morphology. The concentration of iron determined by AAS-ET (Figure $5 \mathrm{~b}$ ) in the control cells was $0.53 \pm 0.02 \mathrm{ng} / 10^{3}$ cells for A549 cells and $0.67 \pm 0.02 \mathrm{ng} / 10^{3}$ cells for BEAS-2B. A significant increase in iron concentration was observed for both A549 and BEAS-2B cells treated with SPIONs or SPION@ $\mathrm{mSiO}_{2}$ (at least a 30-fold increase). In both cell types, the content of iron was higher in the case of the SPIONs due to the fact that the nanoparticles were delivered to the cells in an equal mass concentration, while almost $30 \%$ of the weight of $\mathrm{SPION} @ \mathrm{mSiO}_{2}$ was accrued by $\mathrm{SiO}_{2}$. BEAS-2B cells incorporated a significantly higher amount of $\mathrm{SPION} @ \mathrm{mSiO}_{2}$ in comparison with A549 cells. No statistically significant differences were observed between BEAS-2B and A549 cells treated with unmodified SPIONs.
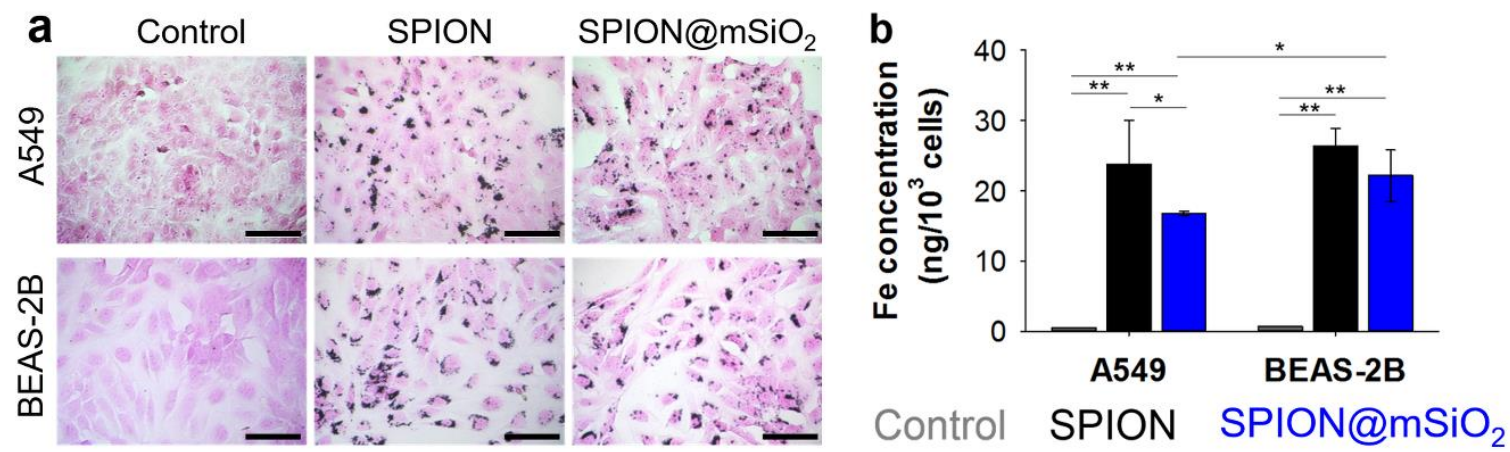

Figure 5. Prussian blue and eosin staining of A549 and BEAS-2B cells incubated with SPIONs or SPION@mSiO2 for $24 \mathrm{~h}$. Scale bar $=100 \mu \mathrm{m}$ (a) and concentration of Fe in the cells (b). Statistically significant differences at $*<0.05$ and ${ }^{* *} p<0.001$. 
Proliferation profiles of the cells incubated with the suspension of nanoparticles (Figure 6a) showed that the growth of A549 cells was not obstructed by the presence of either SPIONs or SPION@mSiO $\mathrm{m}_{2}$. Surprisingly, the proliferation of BEAS-2B cells was hampered after the addition of the nanoparticles. Untreated (control) BEAS-2B cells reached the maximal values of the cell index (indicating full confluence) after 86-90 h. Nanoparticle-treated BEAS-2B cells did not fully cover the available surface until the end of experiment, although their proliferation increased in the last $20 \mathrm{~h}$ of incubation. Live/dead staining performed after 3 days of incubation with nanoparticles (Figure 6b) did not show an increased number of dead cells in the case of BEAS-2B cells. All cells exhibited typical morphology that did not differ from control cells. The levels of released LDH (Figure 6c) were similar for all samples; no statistically significant differences were observed.
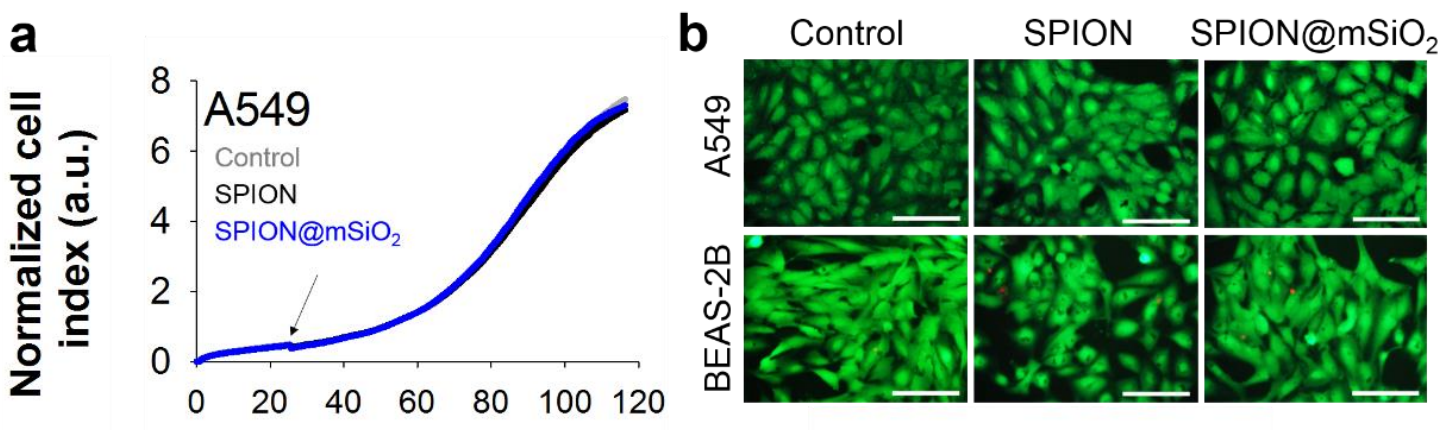

Time (h)

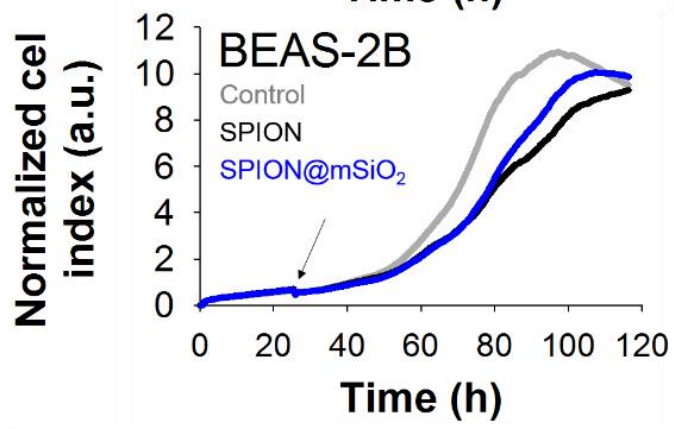

C

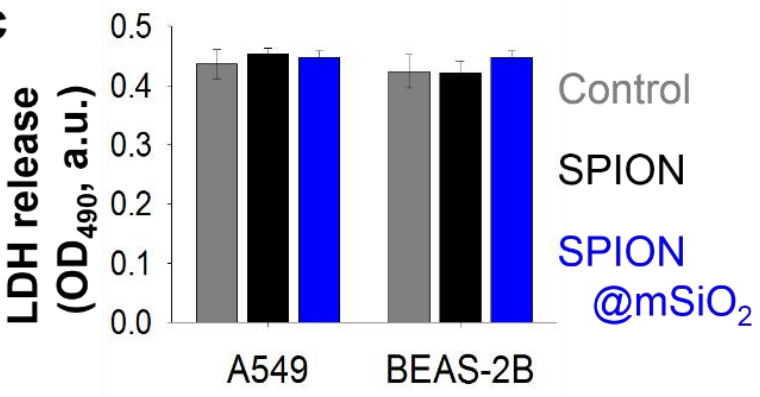

Figure 6. Proliferation profiles (arrows indicate addition of nanoparticles) (a), live/dead images (scale bar $=100 \mu \mathrm{m})(\mathbf{b})$ and lactate dehydrogenase $(\mathrm{LDH})$ release $(\mathbf{c})$ of A549 and BEAS-2B cells incubated with $10 \mu \mathrm{g} / \mathrm{mL}$ SPIONs or SPION@ $\mathrm{mSiO}_{2}$ for 3 days.

The analysis of cell migration revealed significant differences between A549 and BEAS-2B cells (Videos-Supplementary Materials). BEAS-2B cells migrated more extensively than A549 cells (Figure 7a).

The average total distance travelled (Figure $7 \mathrm{~b}$ ) by untreated A549 cells was $41 \pm 7 \mu \mathrm{m}$ and for control BEAS-2B cells it was $100 \pm 21 \mu \mathrm{m}$. The addition of SPIONs or SPION@mSiO $\mathrm{m}_{2}$ did not influence the migration of A549 cells (total distances were $42 \pm 7 \mu \mathrm{m}$ and $41 \pm 5 \mu \mathrm{m}$, respectively). In the case of BEAS-2B cells treated with SPIONs and SPION@ $\mathrm{mSiO}_{2}$, the length of the cell paths increased to $135 \pm 28 \mu \mathrm{m}$ and $140 \pm 27 \mu \mathrm{m}$, respectively. The average velocity of nanoparticle-treated A549 cells was comparable to untreated cells, regardless of nanoparticle type (between $0.55-0.59 \mu \mathrm{m} / \mathrm{h}$ ). The addition of either SPIONs or SPION@ $\mathrm{mSiO}_{2}$ significantly increased the average velocity of BEAS-2B cells

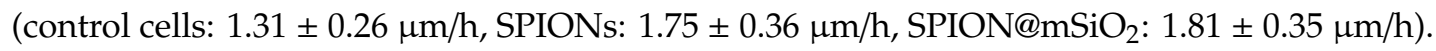

The same phase contrast images were used for the analysis of cell number (Figure $7 \mathrm{c}$ ). SPION@mSiO 2 -treated A549 cells were proliferating at the same rate as their untreated counterparts. The number of A549 cells was not influenced by the addition of nanoparticles. On the contrary, significant differences were found for BEAS-2B cells. Before the treatment, the growth of BEAS-2B cells in both groups was at the same level. After the addition of the nanoparticles, the number of BEAS-2B cells was constant for the initial $24-28 \mathrm{~h}$ post treatment. Then, the proliferation of BEAS-2B 
cells increased again and neared to the level of untreated cells by the end of the experiment. Untreated BEAS-2B cells proliferated at steady rate up to $84 \mathrm{~h}$ (almost 100\% confluence). During the first $24 \mathrm{~h}$ after the treatment, the migration of BEAS-2B cells intensified and the cell number did not change until all SPION@ $\mathrm{mSiO}_{2}$ agglomerates were incorporated by the cells.

a

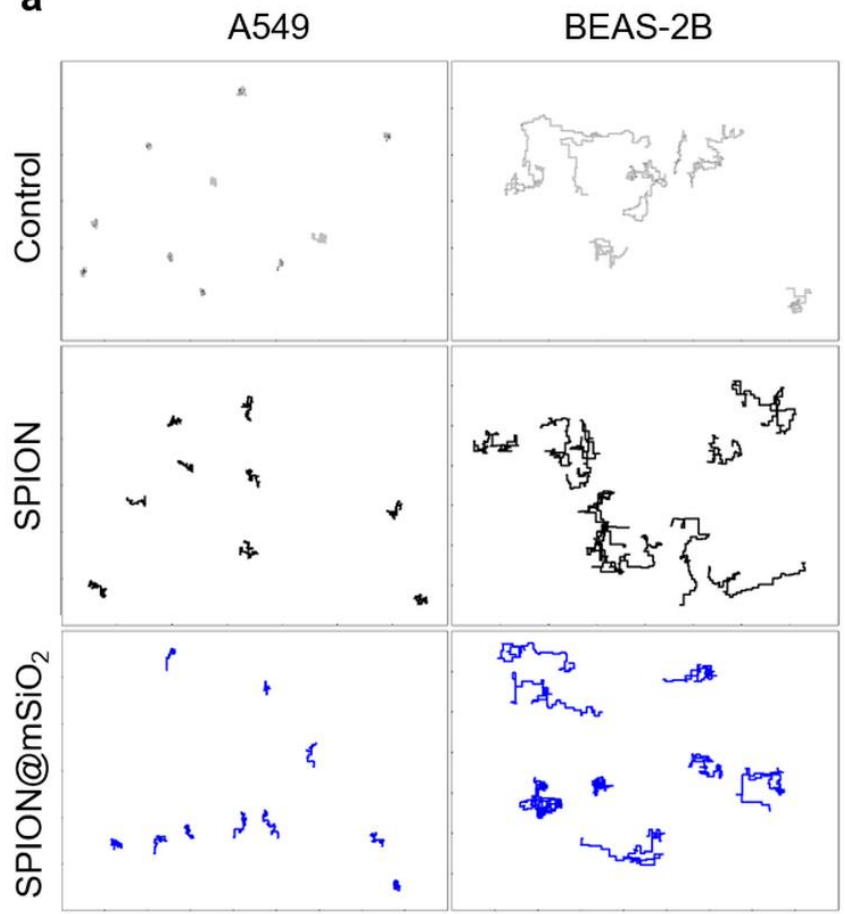

b

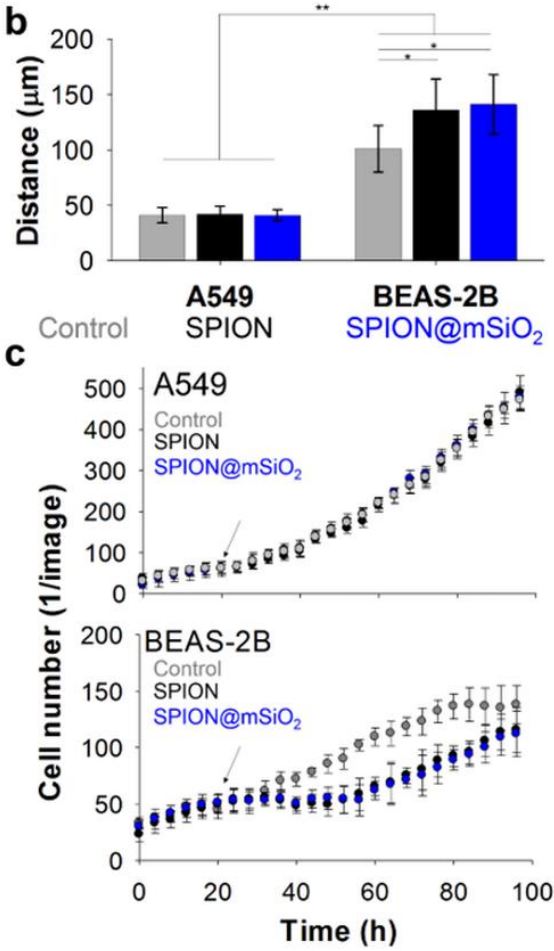

Figure 7. Line traces (after the treatment) (a), total distance travelled (b) and cell number (c) of A549 and BEAS-2B cells incubated with SPIONs or SPION@ $\mathrm{mSiO}_{2}$. Statistically significant differences at * $p<0.05$ and ** $p<0.001$.

\section{Discussion}

The following study was aimed at the development of versatile SPIONs modified with silica coatings for the prevention of iron release and the creation of a platform for the diagnosis and therapy of lung cancer. Silica coatings were successfully deposited on the SPIONs. The chemical composition of all modified SPIONs was similar, as proved by FTIR. The amount of silica deposited on the SPIONs varied slightly between the samples and it was the highest for $\mathrm{SPION} @ \mathrm{SiO}_{2} @ \mathrm{mSiO}_{2}$, as evidenced by both FTIR and the analysis of magnetic properties. The most uniform coating was obtained for SPION@ $\mathrm{mSiO}_{2}$, as evidenced by TEM analysis.

The presence of a silica shell decreased the magnetization of the modified SPIONs. The saturation magnetization decreased in inverse proportion to the amount of silica deposited on the SPIONs. The changes in saturation magnetization of the modified SPIONs were similar to those reported by others $[28,37,38]$ and the magnetic properties of all the modified SPIONs were comparable with other materials used in hyperthermia: minimal $\mathrm{M}_{\mathrm{S}}$, adaptable for biomedical purposes, were reported to be $7-22 \mathrm{emu} / \mathrm{g}[13,39]$. The thickness of the silica layer can be modified by adjusting the amount of TEOS used for the sol-gel process, as evidenced by Deng et al. [28]. A higher amount of TEOS, i.e., a silica precursor, resulted in the formation of thicker coatings. However, the same study reported that the magnetic properties of silica-coated SPIONs deteriorated proportionally to the increased coating thickness.

Deposited coatings significantly influenced the surface properties of the SPIONs. The most pronounced changes were observed for SPION@ $\mathrm{mSiO}_{2}$. A single $@ \mathrm{mSiO}_{2}$ coating effectively inhibited the dissolution of iron and its release from the nanoparticles (more than 10-fold decrease compared to 
the unmodified SPIONs). The prevention of iron release from the SPIONs was of utmost importance, since iron is considered as a cofactor in cancer cell proliferation [23,40]. SPION@ $\mathrm{mSiO}_{2}$ nanoparticles were characterized by the highest surface area and the lowest surface zeta potential among all the modified SPIONs. Interestingly, the highest surface area was observed for SPION@ $\mathrm{mSiO}_{2}$, while the surface area of SPION@SiO 2 and SPION@SiO $\mathrm{S}_{2} @ \mathrm{mSiO}_{2}$ were at a similar level. Considering that the BET surface area was dependent on the outermost layer, it was expected that the surface area of SPION@SiO ${ }_{2} @ \mathrm{mSiO}_{2}$ should have been close to $\mathrm{SPION} @ \mathrm{mSiO}_{2}$. However, the results of the magnetic properties testing showed that the deposition of an $\mathrm{mSiO}_{2}$ coating on $\mathrm{SPION@SiO} 2$ increased the total silica content in $\mathrm{SPION} @ \mathrm{SiO}_{2} @ \mathrm{mSiO}_{2}$ by only approximately 3.6\%, as compared to SPION@SiO 2 . This indicated that the deposition of $\mathrm{mSiO}_{2}$ on $\mathrm{SPION@SiO}{ }_{2}$ was less successful than on the unmodified

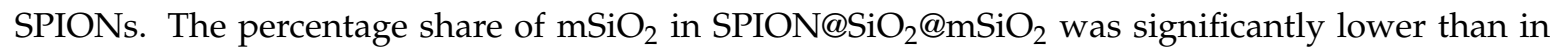
SPION@mSiO ${ }_{2}$, thus the increase in the BET surface area was less prominent. The coating was uniform in terms of its mechanical properties and integrity, as evidenced by AFM topography and phase imaging.

SPION@ $\mathrm{mSiO}_{2}$ offered the highest surface area available for prospective loading with biologically active molecules (e.g., peptides, siRNA) and the sufficient inhibition of iron release (no statistically significant differences in iron release between SPION@SiO ${ }_{2}, \mathrm{SPION} @ \mathrm{mSiO}_{2}$ and SPION@SiO${ }_{2} @ \mathrm{mSiO}_{2}$ ).

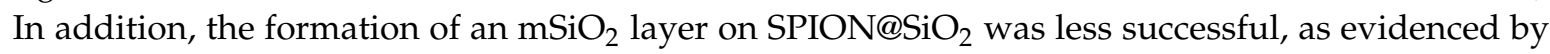
the measurements of the magnetic properties. The deposition of an $\mathrm{mSiO}_{2}$ layer on SPION@SiO nanoparticles, leading to the formation of SPION@SiO${ }_{2} @ \mathrm{mSiO}_{2}$, increased the silica content only by $3.6 \%$ (to compare-the percentage silica share in $\mathrm{SPION} @ \mathrm{mSiO}_{2}$ was $29.3 \%$ ). Thus, $\mathrm{SPION} @ \mathrm{SiO}_{2}$ was selected from all the modified nanoparticles for further in vitro studies aimed at the evaluation of its cytotoxicity in contact with human lung epithelial cells.

The uptake of SPIONs and SPION@ $\mathrm{mSiO}_{2}$ by human lung epithelial cells of carcinoma (A549) and normal (BEAS-2B) origin was evaluated at the beginning. As shown by Prussian blue and eosin staining as well as AAS-ET measurements, both types of the nanoparticles were efficiently incorporated by the cells. The nanoparticles agglomerated inside the cells and the majority of them were accumulated around the nuclei. Although the detailed mechanism of the nanoparticle uptake was not the objective of the following research, the information on the ways in which the nanoparticles enter the cells can be found in the literature. Kim et al. [10] analyzed the uptake by A549 cells of cobalt ferrite magnetic nanoparticles covered with a silica layer. The uptake of the nanoparticles was blocked at a low temperature $\left(4^{\circ} \mathrm{C}\right)$ or in the presence of certain metabolic inhibitors (including sodium azide, sucrose and bafilomycin A). It was demonstrated that the nanoparticles were internalized by the cells through an energy-dependent endosomal-lysosomal mechanism.

The presence of the nanoparticles strongly influenced the proliferation of BEAS-2B cells, while it did not affect A549 cells. It is noteworthy that no signs of increased cytotoxicity or irritation were observed, indicating that neither the SPIONs nor SPION@ $\mathrm{mSiO}_{2}$ damaged the cells. The levels of LDH released to the cell culture medium in nanoparticle-treated BEAS-2B cells were the same as for the control cells.

The noticeable differences were found in the behavior of A549 and BEAS-2B cells incubated with the nanoparticles. The analyses were focused only on the time after the addition of the nanoparticles. In general, the motility of the A549 cells was significantly lower than that of BEAS-2B cells. One of the reasons for that could be the different morphology of these two cell types. A549 cells are small, carcinoma-derived cells growing closely with each other and forming colonies characteristic of malignant cells. BEAS-2B cells are of normal origin, they are much bigger than A549 cells, they have widespread cytoplasm and they do not tend to form clusters. Around the clock analysis of cell behavior showed that the A549 cells were growing normally and incorporated the nanoparticles once they were in close proximity to the cell. On the other hand, the BEAS-2B cells migrated more extensively, covering greater areas of the well, being able to incorporate almost all of the nanoparticles within the first $24 \mathrm{~h}$ post treatment. The results of the cell migration analyses confirmed that the decrease in proliferation 
of the BEAS-2B cells in the presence of SPIONs or SPION@mSiO 2 was not caused by the cytotoxicity of the nanoparticles. To fully understand this phenomenon, additional studies focusing on the influence of the nanoparticles on e.g., the cell cycle and the expression of pro-inflammatory cytokines (i.e., IL-6) and actin-bundling protein (i.e., fascin-1), are necessary [41]. The increased migration of the BEAS-2B cells may be associated with their natural tendency for remodeling. In response to an injury, the airway epithelium can undergo a remodeling process [42]. It may be related to the repair of any structural changes that can occur during lung development or after an acute injury. It is a natural and physiological process that allows for the restoration of the normal airway structure and function. However, chronic lung injuries or inflammation (e.g., in asthma patients) can lead to pathological airway remodeling, leading to wall thickening, the hypertrophy of smooth muscle cells and the hypersecretion of mucus [43].

The developed silica-coated SPIONs can be also considered as a versatile carrier used in lung cancer treatment, either alone or as a component of composite inhalable drug delivery systems. The latter is particularly interesting, as the addition of magnetic nanoparticles in polymeric [44] or lipid [45,46] drug delivery carriers or liposomes [47] allows for guided accumulation in the desired area of the lungs with the use of an external magnetic field. Our team had already used SPION@ $\mathrm{mSiO}_{2}$ as a component of the inhalable fatty acid-based microparticles loaded with paclitaxel [46]. The reasoning behind such a design for the drug carrier system was as follows: upon inhalation, the microparticles will be drawn to the tumor site using an external magnetic field. Then an alternating electromagnetic field will be applied, which will lead to the heating up of the magnetic nanoparticles, the melting of the fatty acid matrix of the microparticles and in consequence the release of paclitaxel directly to the tumor site. The composite microparticles had physicochemical properties suitable for such an application (e.g., appropriate size, melting temperature and mobility in a magnetic field). In vitro studies showed the efficient inhibition of A549 malignant lung epithelial cells, while empty microparticles or those loaded only with SPION@ $\mathrm{mSiO}_{2}$ did not influence the cell viability, paving the way for the potential application of a developed system in lung cancer treatment.

\section{Conclusions}

In this study, SPIONs were modified with silica coatings of different morphologies and the physicochemical properties of the obtained nanoparticles were characterized by various techniques. The magnetic properties of modified SPIONs changed but remained adequate for hyperthermia treatment. It was shown that the presence of a silica coating significantly inhibited the release of iron from SPIONs and thus enabled the use of such nanoparticles for the diagnosis and treatment of cancer. At the same time, the applied coatings increased the surface area of SPIONs, providing a platform for further loading of drugs or other moieties. In the end, SPIONs and SPIONs coated with a single mesporous silica layer were proven to be cytocompatible with lung epithelial cells. The developed SPION-based carriers can be enriched in anticancer drugs or biologically active molecules and administered to the patient e.g., via inhalation directly to the lung tumor. It is expected that magnetic hyperthermia treatment coupled with the delivery of cancer suppression factors will increase the efficacy of the treatment.

Supplementary Materials: The following are available online at http://www.mdpi.com/2079-4991/10/6/1076/s1, Video S1: Growth of A549 control cells, Video S2: Growth of A549 cells incubated with $10 \mu \mathrm{g} / \mathrm{mL}$ of SPION,

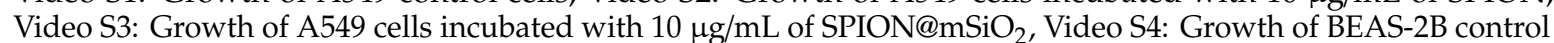
cells, Video S5: Growth of BEAS-2B cells incubated with $10 \mu \mathrm{g} / \mathrm{mL}$ of SPION, Video S6: Growth of BEAS-2B cells incubated with $10 \mu \mathrm{g} / \mathrm{mL}$ of SPION@ $\mathrm{mSiO}_{2}$.

Author Contributions: Conceptualization, K.R., M.M., E.P. and W.C.; methodology, K.R., A.Z., W.R., K.K. and W.C.; software, K.R., A.Z., W.R., K.K. and W.C.; validation, K.R., M.M., W.R., E.P. and W.C.; formal analysis, K.R., E.P. and W.C.; investigation, K.R., A.Z., W.R., K.K. and W.C.; resources, E.P.; data curation, K.R.; writing-original draft preparation, K.R., E.P. and W.C.; writing-review and editing, K.R., E.P.; visualization, K.R.; supervision, E.P. and W.C.; project administration, E.P.; funding acquisition, E.P. All authors have read and agreed to the published version of the manuscript. 
Funding: This study was supported by the National Science Centre Poland (No 2014/14/M/ST5/00649).

Acknowledgments: The authors would also like to acknowledge Aleksandr Mironov at the Electron Microscopy Facility at The Faculty of Biology, Medicine and Health, The University of Manchester, UK for TEM imaging and the Bosch Institute at the University of Sydney for the access to the equipment.

Conflicts of Interest: The authors declare no conflict of interest.

\section{References}

1. Laurent, S.; Forge, D.; Port, M.; Roch, A.; Robic, C.; Elst, L.V.; Muller, R.N. Magnetic iron oxide nanoparticles: Synthesis, stabilization, vectorization, physicochemical characterizations, and biological applications. Chem. Rev. 2008, 108, 2064-2110. [CrossRef] [PubMed]

2. Gupta, A.K.; Gupta, M. Synthesis and surface engineering of iron oxide nanoparticles for biomedical applications. Biomaterials 2005, 26, 3995-4021. [CrossRef] [PubMed]

3. Gobbo, O.L.; Wetterling, F.; Vaes, P.; Teughels, S.; Markos, F.; Edge, D.; Shortt, C.M.; Crosbie-Staunton, K.; Radomski, M.W.; Volkov, Y. Biodistribution and pharmacokinetic studies of SPION using particle electron paramagnetic resonance, MRI and ICP-MS. Nanomedicine 2015, 10, 1751-1760. [CrossRef] [PubMed]

4. Yan, L.; Luo, L.; Amirshaghaghi, A.; Miller, J.; Meng, C.; You, T.; Busch, T.M.; Tsourkas, A.; Cheng, Z. Dextran-benzoporphyrin derivative (BPD) coated superparamagnetic iron oxide nanoparticle (SPION) micelles for T2-weighted magnetic resonance imaging and photodynamic therapy. Bioconjugate Chem. 2019, 30, 2974-2981. [CrossRef]

5. Pöttler, M.; Schreiber, E.; Dürr, S.; Döllinger, M.; Alexiou, C. Regenerative medicine of the vocal fold: Magnetic tissue engineering (MTE) using superparamagnetic iron oxide nanoparticles. Laryngo Rhino Otol. 2018, 97, 10385. [CrossRef]

6. Li, C.; Armstrong, J.P.; Pence, I.J.; Kit-Anan, W.; Puetzer, J.L.; Carreira, S.C.; Moore, A.C.; Stevens, M.M. Glycosylated superparamagnetic nanoparticle gradients for osteochondral tissue engineering. Biomaterials 2018, 176, 24-33. [CrossRef]

7. Adams, S.A.; Hauser, J.L.; Allen, A.L.C.; Lindquist, K.P.; Ramirez, A.P.; Oliver, S.; Zhang, J.Z. $\mathrm{Fe}_{3} \mathrm{O}_{4} @$ $\mathrm{SiO}_{2}$ nanoparticles functionalized with gold and poly (vinylpyrrolidone) for bio-separation and sensing applications. ACS Appl. Nano Mater. 2018, 1, 1406-1412. [CrossRef]

8. Tewes, F.; Ehrhardt, C.; Healy, A.M. Superparamagnetic iron oxide nanoparticles (SPIONs)-loaded Trojan microparticles for targeted aerosol delivery to the lung. Eur. J. Pharm. Biopharm. 2014, 86, 98-104. [CrossRef]

9. Jeon, H.; Kim, J.; Lee, Y.M.; Kim, J.; Choi, H.W.; Lee, J.; Park, H.; Kang, Y.; Kim, I.-S.; Lee, B.-H. Poly-paclitaxel/cyclodextrin-SPION nano-assembly for magnetically guided drug delivery system. J. Control. Release 2016, 231, 68-76. [CrossRef]

10. Amirshaghaghi, A.; Yan, L.; Miller, J.; Daniel, Y.; Stein, J.M.; Busch, T.M.; Cheng, Z.; Tsourkas, A. Chlorin e6-coated superparamagnetic iron oxide nanoparticle (SPION) nanoclusters as a theranostic agent for dual-mode imaging and photodynamic therapy. Sci. Rep. 2019, 9, 2613. [CrossRef]

11. Sun, X.; Liu, B.; Chen, X.; Lin, H.; Peng, Y.; Li, Y.; Zheng, H.; Xu, Y.; Ou, X.; Yan, S. Aptamer-assisted superparamagnetic iron oxide nanoparticles as multifunctional drug delivery platform for chemo-photodynamic combination therapy. J. Mater. Sci. Mater. Med. 2019, 30, 76. [CrossRef] [PubMed]

12. Hayashi, K.; Nakamura, M.; Sakamoto, W.; Yogo, T.; Miki, H.; Ozaki, S.; Abe, M.; Matsumoto, T.; Ishimura, K. Superparamagnetic nanoparticle clusters for cancer theranostics combining magnetic resonance imaging and hyperthermia treatment. Theranostics 2013, 3, 366-376. [CrossRef] [PubMed]

13. Hergt, R.; Dutz, S.; Müller, R.; Zeisberger, M. Magnetic particle hyperthermia: Nanoparticle magnetism and materials development for cancer therapy. J. Phys. Condens. Matter 2006, 18, S2919. [CrossRef]

14. Guardia, P.; Di Corato, R.; Lartigue, L.; Wilhelm, C.; Espinosa, A.; Garcia-Hernandez, M.; Gazeau, F.; Manna, L.; Pellegrino, T. Water-soluble iron oxide nanocubes with high values of specific absorption rate for cancer cell hyperthermia treatment. ACS Nano 2012, 6, 3080-3091. [CrossRef]

15. Ahmed, K.; Tabuchi, Y.; Kondo, T. Hyperthermia: An effective strategy to induce apoptosis in cancer cells. Apoptosis 2015, 20, 1411-1419. [CrossRef]

16. Gupta, A.K.; Naregalkar, R.R.; Vaidya, V.D.; Gupta, M. Recent advances on surface engineering of magnetic iron oxide nanoparticles and their biomedical applications. Nanomedicine 2007, 2, 23-39. [CrossRef] 
17. Lachowicz, D.; Kaczyńska, A.; Wirecka, R.; Kmita, A.; Szczerba, W.; Bodzoń-Kułakowska, A.; Sikora, M.; Karewicz, A.; Zapotoczny, S. A hybrid system for magnetic hyperthermia and drug delivery: SPION functionalized by curcumin conjugate. Materials 2018, 11, 2388. [CrossRef]

18. Mansouri, M.; Nazarpak, M.H.; Solouk, A.; Akbari, S.; Hasani-Sadrabadi, M.M. Magnetic responsive of paclitaxel delivery system based on SPION and palmitoyl chitosan. J. Magn. Magn. Mater. 2017, 421, 316-325. [CrossRef]

19. Hauser, A.K.; Anderson, K.W.; Hilt, J.Z. Peptide conjugated magnetic nanoparticles for magnetically mediated energy delivery to lung cancer cells. Nanomedicine 2016, 11, 1769-1785. [CrossRef]

20. Abdelaziz, H.M.; Gaber, M.; Abd-Elwakil, M.M.; Mabrouk, M.T.; Elgohary, M.M.; Kamel, N.M.; Kabary, D.M.; Freag, M.S.; Samaha, M.W.; Mortada, S.M. Inhalable particulate drug delivery systems for lung cancer therapy: Nanoparticles, microparticles, nanocomposites and nanoaggregates. J. Control. Release 2018, 269, 374-392. [CrossRef]

21. Sadhukha, T.; Wiedmann, T.S.; Panyam, J. Inhalable magnetic nanoparticles for targeted hyperthermia in lung cancer therapy. Biomaterials 2013, 34, 5163-5171. [CrossRef] [PubMed]

22. Price, D.N.; Stromberg, L.R.; Kunda, N.K.; Muttil, P. In vivo pulmonary delivery and magnetic-targeting of dry powder nano-in-microparticles. Mol. Pharm. 2017, 14, 4741-4750. [CrossRef] [PubMed]

23. Steegmann-Olmedillas, J.L. The role of iron in tumour cell proliferation. Clin. Transl. Oncol. 2011, 13, 71-76. [CrossRef] [PubMed]

24. Anbarasu, M.; Anandan, M.; Chinnasamy, E.; Gopinath, V.; Balamurugan, K. Synthesis and characterization of polyethylene glycol (PEG) coated $\mathrm{Fe}_{3} \mathrm{O}_{4}$ nanoparticles by chemical co-precipitation method for biomedical applications. Spectrochim. Acta Part A Mol. Biomol. Spectrosc. 2015, 135, 536-539. [CrossRef]

25. Strehl, C.; Maurizi, L.; Gaber, T.; Hoff, P.; Broschard, T.; Poole, A.R.; Hofmann, H.; Buttgereit, F. Modification of the surface of superparamagnetic iron oxide nanoparticles to enable their safe application in humans. Int. J. Nanomed. 2016, 11, 5883-5896. [CrossRef]

26. Ma, H.-1.; Qi, X.-r.; Maitani, Y.; Nagai, T. Preparation and characterization of superparamagnetic iron oxide nanoparticles stabilized by alginate. Int. J. Pharm. 2007, 333, 177-186. [CrossRef]

27. Keshtkar, M.; Shahbazi-Gahrouei, D.; Mehrgardi, M.; Aghaei, M. Synthesis and cytotoxicity assessment of gold-coated magnetic iron oxide nanoparticles. J. Biomed. Phys. Eng. 2018, 8. [CrossRef]

28. Deng, Y.-H.; Wang, C.-C.; Hu, J.-H.; Yang, W.-L.; Fu, S.-K. Investigation of formation of silica-coated magnetite nanoparticles via sol-gel approach. Colloids Surf. A Physicochem. Eng. Asp. 2005, 262, 87-93. [CrossRef]

29. Figueira, R.; Silva, C.J.; Pereira, E. Organic-inorganic hybrid sol-gel coatings for metal corrosion protection: A review of recent progress. J. Coat. Technol. Res. 2015, 12, 1-35. [CrossRef]

30. Hamzian, N.; Hashemi, M.; Ghorbani, M.; Bahreyni Toosi, M.H.; Ramezani, M. Preparation, optimization and toxicity evaluation of (SPION-PLGA) \pm PEG nanoparticles loaded with gemcitabine as a multifunctional nanoparticle for therapeutic and diagnostic applications. Iran. J. Pharm. Res. 2017, 16, 8-21.

31. Mulens-Arias, V.; Rojas, J.M.; Sanz-Ortega, L.; Portilla, Y.; Pérez-Yagüe, S.; Barber, D.F. Polyethylenimine-coated superparamagnetic iron oxide nanoparticles impair in vitro and in vivo angiogenesis. Nanomed. Nanotechnol. Biol. Med. 2019, 21, 102063. [CrossRef] [PubMed]

32. Alpsoy, L.; Baykal, A.; Akal, Z.Ü. Luteolin-loaded spion as a drug carrier for cancer cell in vitro. J. Supercond. Nov. Magn. 2018, 31, 467-474. [CrossRef]

33. Kim, J.; Kim, H.S.; Lee, N.; Kim, T.; Kim, H.; Yu, T.; Song, I.C.; Moon, W.K.; Hyeon, T. Multifunctional uniform nanoparticles composed of a magnetite nanocrystal core and a mesoporous silica shell for magnetic resonance and fluorescence imaging and for drug delivery. Angew. Chem. Int. Ed. 2008, 47, 8438-8441. [CrossRef] [PubMed]

34. Zhu, X.-M.; Wang, Y.-X.J.; Leung, K.C.-F.; Lee, S.-F.; Zhao, F.; Wang, D.-W.; Lai, J.M.; Wan, C.; Cheng, C.H.; Ahuja, A.T. Enhanced cellular uptake of aminosilane-coated superparamagnetic iron oxide nanoparticles in mammalian cell lines. Int. J. Nanomed. 2012, 7, 953-964. [CrossRef]

35. Schneider, C.A.; Rasband, W.S.; Eliceiri, K.W. NIH Image to ImageJ: 25 years of image analysis. Nat. Methods 2012, 9, 671-675. [CrossRef] [PubMed]

36. Magonov, S.; Elings, V.; Whangbo, M.-H. Phase imaging and stiffness in tapping-mode atomic force microscopy. Surf. Sci. 1997, 375, L385-L391. [CrossRef] 
37. Deng, Y.; Qi, D.; Deng, C.; Zhang, X.; Zhao, D. Superparamagnetic high-magnetization microspheres with an $\mathrm{Fe}_{3} \mathrm{O}_{4} @ \mathrm{SiO}_{2}$ core and perpendicularly aligned mesoporous $\mathrm{SiO}_{2}$ shell for removal of microcystins. J. Am. Chem. Soc. 2008, 130, 28-29. [CrossRef]

38. Li, K.; Zeng, Z.; Xiong, J.; Yan, L.; Guo, H.; Liu, S.; Dai, Y.; Chen, T. Fabrication of mesoporous $\mathrm{Fe}_{3} \mathrm{O}_{4} @ S_{2} \mathrm{~S}_{2} @ \mathrm{CTAB}-\mathrm{SiO}_{2}$ magnetic microspheres with a core/shell structure and their efficient adsorption performance for the removal of trace PFOS from water. Colloids Surf. A Physicochem. Eng. Asp. 2015, 465, 113-123. [CrossRef]

39. Lee, J.-H.; Jang, J.-T.; Choi, J.-S.; Moon, S.H.; Noh, S.-H.; Kim, J.-W.; Kim, J.-G.; Kim, I.-S.; Park, K.I.; Cheon, J. Exchange-coupled magnetic nanoparticles for efficient heat induction. Nat. Nanotechnol. 2011, 6, 418-422. [CrossRef]

40. Manz, D.H.; Blanchette, N.L.; Paul, B.T.; Torti, F.M.; Torti, S.V. Iron and cancer: Recent insights. Ann. N. Y. Acad. Sci. 2016, 1368, 149-161. [CrossRef]

41. Adams, J.C. Roles of fascin in cell adhesion and motility. Curr. Opin. Cell Biol. 2004, 16, 590-596. [CrossRef] [PubMed]

42. Wang, W.C.; Kuo, C.Y.; Tzang, B.S.; Chen, H.M.; Kao, S.H. IL-6 augmented motility of airway epithelial cell BEAS-2B via Akt/GSK-3ß signaling pathway. J. Cell. Biochem. 2012, 113, 3567-3575. [CrossRef] [PubMed]

43. Fehrenbach, H.; Wagner, C.; Wegmann, M. Airway remodeling in asthma: What really matters. Cell Tissue Res. 2017, 367, 551-569. [CrossRef] [PubMed]

44. Miranda, M.S.; Rodrigues, M.T.; Domingues, R.M.A.; Torrado, E.; Reis, R.L.; Pedrosa, J.; Gomes, M.E. Exploring inhalable polymeric dry powders for anti-tuberculosis drug delivery. Mater. Sci. Eng. C 2018, 93, 1090-1103. [CrossRef]

45. Upadhyay, D.; Scalia, S.; Vogel, R.; Wheate, N.; Salama, R.O.; Young, P.M.; Traini, D.; Chrzanowski, W. Magnetised thermo responsive lipid vehicles for targeted and controlled lung drug delivery. Pharm. Res. 2012, 29, 2456-2467. [CrossRef] [PubMed]

46. Reczyńska, K.; Marchwica, P.; Khanal, D.; Borowik, T.; Langner, M.; Pamuła, E.; Chrzanowski, W. Stimuli-sensitive fatty acid-based microparticles for the treatment of lung cancer. Mater. Sci. Eng. C 2020, 110801. [CrossRef]

47. Nahar, K.; Absar, S.; Patel, B.; Ahsan, F. Starch-coated magnetic liposomes as an inhalable carrier for accumulation of fasudil in the pulmonary vasculature. Int. J. Pharm. 2014, 464, 185-195. [CrossRef] 